\author{
S. Sangaroon*, W. Tuisakda \\ Department of Physics, Faculty of Science, Mahasarakham University, Mahasarakham, Thailand \\ *Corresponding author: siriyaporn.s@msu.ac.th
}

\title{
STUDY OF BREMSSTRAHLUNG PHOTONS IN BULK TARGET USING MCNP CODE
}

The aim of this research was to study the feasibility of bremsstrahlung photon production in target bombarded by $1 \mathrm{GeV}$ electrons. The calculations were performed by the Monte Carlo code MCNP. Six target materials with densities between 2 and $20 \mathrm{~g} / \mathrm{cm}^{3}$ were studied. The bremsstrahlung photon flux is high for the target density above $8 \mathrm{~g} / \mathrm{cm}^{3}$. Copper is the best target for $1 \mathrm{GeV}$ electron beam due to high bremsstrahlung photon production, low scattering and low transmission electron flux. The copper target was altered to have different thicknesses between 0.01 and $2.5 \mathrm{~cm}$. The results showed that the bremsstrahlung photon flux significantly increased when the target thickness increased from 0.01 to $1.5 \mathrm{~cm}$. The angular distribution of the bremsstrahlung photons with angles between 0 and 120 degrees was determined for copper target. The maximum angle of the photon scattering was about 20 degree.

Keywords: bremsstrahlung, electron beam, MCNP simulation.

\section{Introduction}

In medical facilities, the bremsstrahlung photons are produced from a thick-target bombarded by electrons with energy up to $40 \mathrm{MeV}$. The bremsstrahlung photons from the target are spread in various directions. Many works have studied the effect of the bremsstrahlung photons expanding due to the variety in the target materials with different bombardment electron energies. DeMarco et al. [1] reported the results of thick-target bremsstrahlung calculations showing the emissions from beryllium, aluminium and lead targets at various angles between 0 and $90^{\circ}$. The targets were bombarded by $15 \mathrm{MeV}$ electrons. Kosako et al. [2] measured the angular distribution of the bremsstrahlung photons between $0^{\circ}$ and $120^{\circ}$ from copper and tungsten targets bombarded by a variety of electron energies (18, 28 and $38 \mathrm{MeV}$ ) from an electron linear accelerator (linac). The results show that the target plays an important role in the production of the bremsstrahlung photons. Different material densities and thicknesses of the target have an influence on the bremsstrahlung photons' distribution and flux.

Currently, electron accelerators are widely used in order to generate bremsstrahlung photons in radiotherapy. At the Thai-Synchrotron, electron accelerators have been developed that create multi Giga-electron volt $(\mathrm{GeV})$ beams [3]. Thus, the utilization of higher electron energies for radiotherapy is considered in this research. The precise estimation of the bremsstrahlung photon distribution from a thick-target bombarded by high energy electrons is necessary for the accurate dose estimation and also for the shielding calculation.

In order to design the target, the simulations using Monte Carlo method are needed. A number of Monte Carlo methods are widely used and available for the electron-photon transport, such MCNP or Monte Carlo N-Particle [1, 2, 4], FLUKA [5, 6] and EGS4 [7], etc. The most advanced code for the electron-photon particle transport is the MCNP, which was used to obtain the results reported in this paper. MCNP is a powerful Monte Carlo code capable of three-dimensional geometry for neutronphoton-electron problems [8]. Therefore, the MCNP has the capability to simulate the target bremsstrahlung photons production, which is important for radiotherapy applications.

In this work, feasibility studies of bremsstrahlung photons produced from target bombarding with high energy electrons $(1 \mathrm{GeV})$ were conducted. The results were based on the MCNP simulations, which considered the main parameters (the target material and the target thickness) of the cylinder target. The results of the bremsstrahlung photon flux and distribution showed the potential ability of the high energy electrons to be utilized in radiotherapy application fields.

The MCNP simulation setup and calculation are reported in section 2. The results of the bremsstrahlung photons from a variety of target materials and thickness and flux angular distribution were obtained and presented in section 3. Finally, the work is concluded in section 4 .

\section{MCNP model and calculation}

The MCNP model and the simulation set up are presented in this section. The calculations were performed using a $1 \mathrm{GeV}$ electron beam. The electrons were fired at a target that was fixed at $5 \mathrm{~cm}$ in a parallel axis to the beam. The tally was set $20 \mathrm{~cm}$ behind the target. The $1 \mathrm{GeV}$ electron beam was designed with a Gaussian spatial distribution of $0.4 \mathrm{~cm}$ radius with $\sigma=0.03$. The full width at half 
maximum (FWHM) of the electron beam energy was $900 \mathrm{keV}$. Three parameters were considered to study the feasibility of this work: 1) target material, 2) target thickness and 3) bremsstrahlung photon angular distribution.

For the first study, six materials with the density range of 2.69 to $19.32 \mathrm{~g} / \mathrm{cm}^{3}$ were selected: aluminum - 2.69; iron - 7.86; copper - 8.25; lead - 11.35; tungsten - 19.30; gold - 19.32. The target was fixed with a diameter of $1 \mathrm{~cm}$ and thickness of $0.5 \mathrm{~cm}$. The FMESH tally [8] was used to obtain the electron and bremsstrahlung photon fluxes.

For the second study, the best material will be selected as a target due to its high capability on the bremsstrahlung photon production. The target diameter of $1 \mathrm{~cm}$ was fixed. The target thicknesses were varied with values of $0.01,0.05,0.1,0.25,0.5$, $0.75,1.0,1.5,2.0$ and $2.5 \mathrm{~cm}$.

In the last study, the angular spectra and distribution of the bremsstrahlung photons were evaluated. The electron beam was fired normally at the selected target with different thickness $(0.01$, $0.05, \quad 0.25, \quad 0.75$ and $2.50 \mathrm{~cm})$ to produce bremsstrahlung photons that were emitted in a variety of directions. F5 tallies as known as point detectors [8] were used in this calculation. The tallies were set at angles between 0 and $120^{\circ}$ with an angular radius of $20 \mathrm{~cm}$ from the target. The model arrangement of the incident electron beam line, the target and the simulation tally is depicted in Fig. 1.

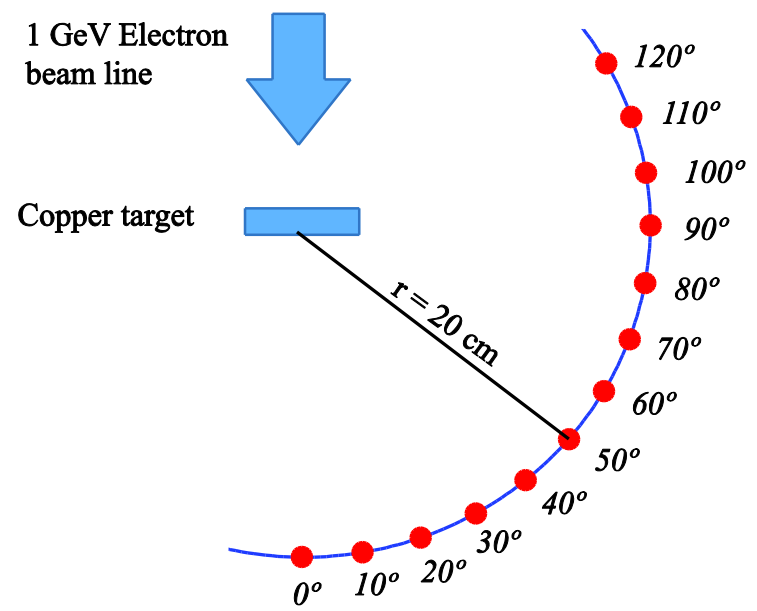

Fig. 1. Simulation model arrangement for electron beam line, target and F5 tallies to calculate the angular distribution of bremsstrahlung photons. (See color Figure on the journal website.)

\section{Results and discussion}

Ideally, the target can produce good quality of the bremsstrahlung photon with high photon flux, low scattering and low electron transmission. The calculation results here show the optimization of the important parameter for the bremsstrahlung photon production.

\subsection{Target material}

The first study is to determine the effect of the target material's density on the flux distribution. The simulation results of the bremsstrahlung photon and transmission electron flux distribution on the plan at $20 \mathrm{~cm}$ perpendicular to the beam have been determined. The mid-plan profiles of the flux are conducted to study the flux intensity and distribution. Fig. 2, $a$ shows the mid-plan profiles of bremsstrahlung photon flux and Fig. $2, b$ shows the mid-plan profiles of transmission electron flux.
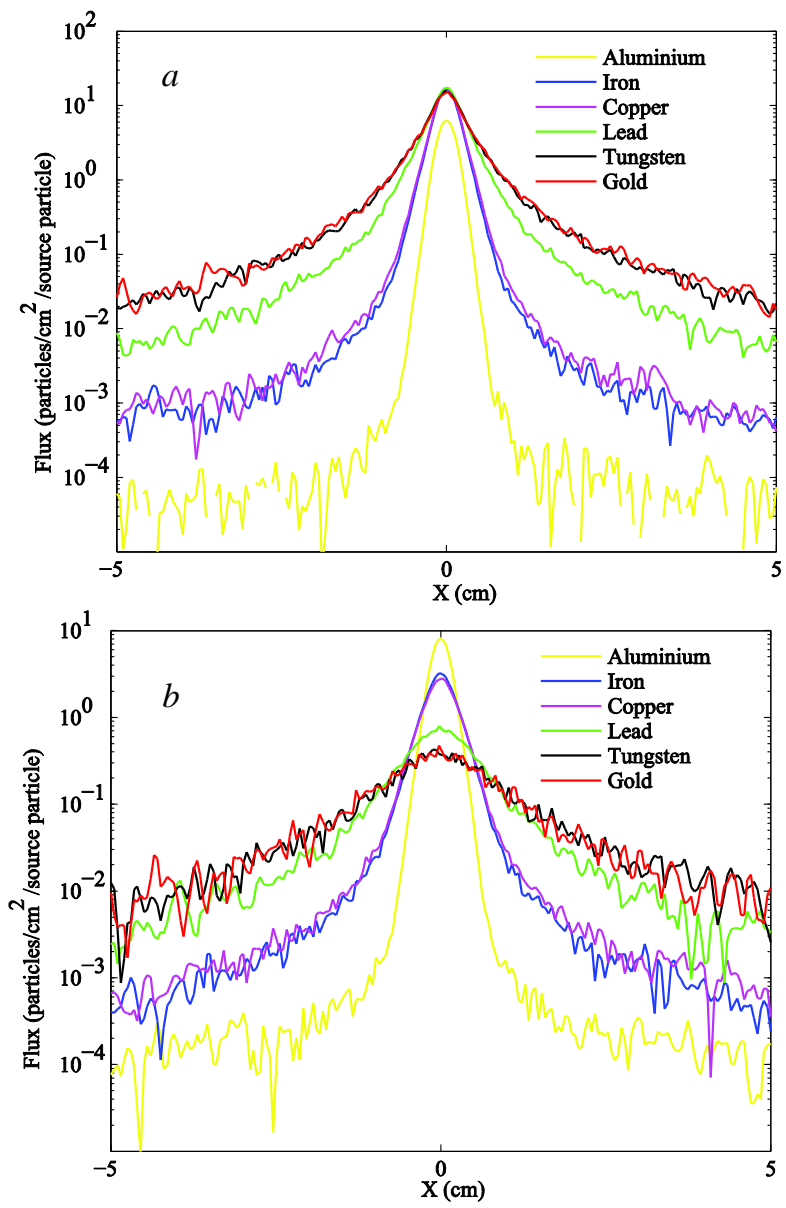

Fig. 2. Mid-plan profile of the bremsstrahlung photon flux (a); mid-plan profile of the transmission electron flux from different target materials $(b)$. (See color Figure on the journal website.)

As shown in the results, the fluxes had a normal distribution, in which the broadening can be explained using the normal distribution fit. The fitting results of the mid-plan profiles of the bremsstrahlung photon and transmission electron flux are presented in Fig. 3.

The electron scattering (in a function of $\sigma$ ) in the low density materials (aluminum and iron) was less than in the high density materials (copper, lead, tungsten and gold), but the flux intensity (in a function of amplitude) was high. For the high density materials, the bremsstrahlung photon flux 
slightly decreased and the bremsstrahlung photon scattering increased proportional to the density of the target. The high density materials above $8 \mathrm{~g} / \mathrm{cm}^{3}$ provided high bremsstrahlung photon flux and low transmission electron flux as shown in Figs. 2 and 3.

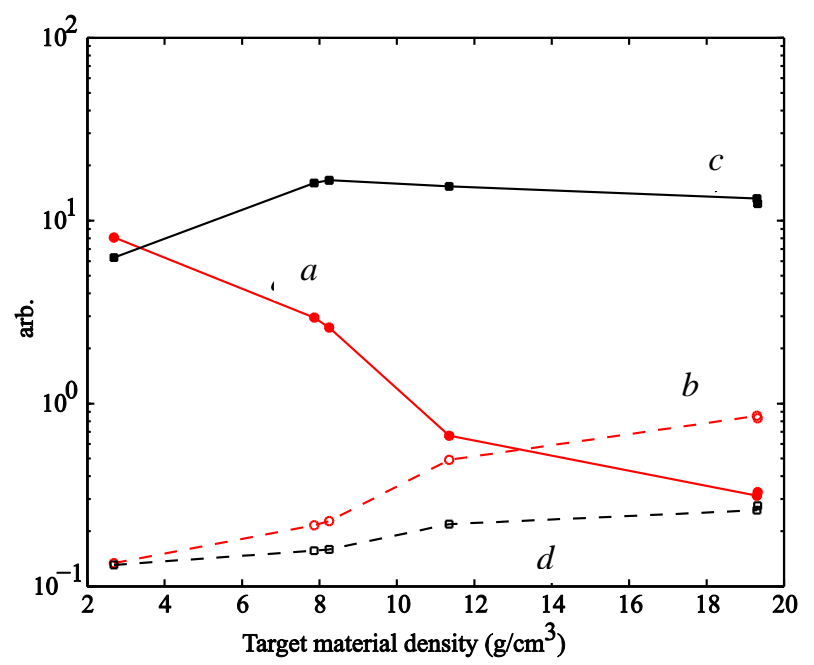

Fig. 3. Mid-plan profile fitted with normal distribution function: $a$ - electron amplitude; $b$ - electron standard deviation $(\sigma) ; c$ - bremsstrahlung photon amplitude; $d$ - bremsstrahlung photon standard deviation $(\sigma)$. (See color Figure on the journal website.)

The integrations over the FMESH detection of the bremsstrahlung photon and transmission electron flux were obtained. The results showed that the bremsstrahlung photon flux increased significantly when the densities of the target were above $8 \mathrm{~g} / \mathrm{cm}^{3}$, approximately. However, due to the high flux distribution of the bremsstrahlung photons and high integrated transmission electron flux, tungsten and gold were not the best targets for the $1 \mathrm{GeV}$ electron beam application.

For this work, the density of the target material was found to significantly effect the bremsstrahlung photon and transmission electron fluxes and the angular scattering. Therefore, copper was selected as the target for the $1 \mathrm{GeV}$ electron beam due to high bremsstrahlung photon production, low bremsstrahlung photon scattering and low transmission electron.

\subsection{Target thickness}

In this work, copper with a density of $8.25 \mathrm{~g} / \mathrm{cm}^{3}$ was selected to study the thickness of the target. Thicknesses between 0.01 and $2.5 \mathrm{~cm}$ were chosen. Similar to the previous study, the flux distribution profile of the bremsstrahlung photons and electrons produced from the target were determined by the FMESH tally. Therefore, the mid-plan profiles of the bremsstrahlung photons and transmission electrons flux distribution were obtained and compared.
The results show that the bremsstrahlung photon and transmission electron fluxes had a normal distribution. The bremsstrahlung photon flux significantly increased when the thickness increased from 0.01 to $0.75 \mathrm{~cm}$ while the transmission electron flux decreased. At thicknesses higher than $0.75 \mathrm{~cm}$, both bremsstrahlung photon and transmission electron fluxes were constant.

Fig. 4 shows the integrated flux over the FMESH detection of the bremsstrahlung photon and transmission electron for different thicknesses of the copper target. The total bremsstrahlung photons increased significantly when the thicknesses increased from 0.01 to $1.5 \mathrm{~cm}$. At thicknesses above $1.5 \mathrm{~cm}$, the total bremsstrahlung photons flux was constant. The total transmission electron flux was not affected by the target thickness.

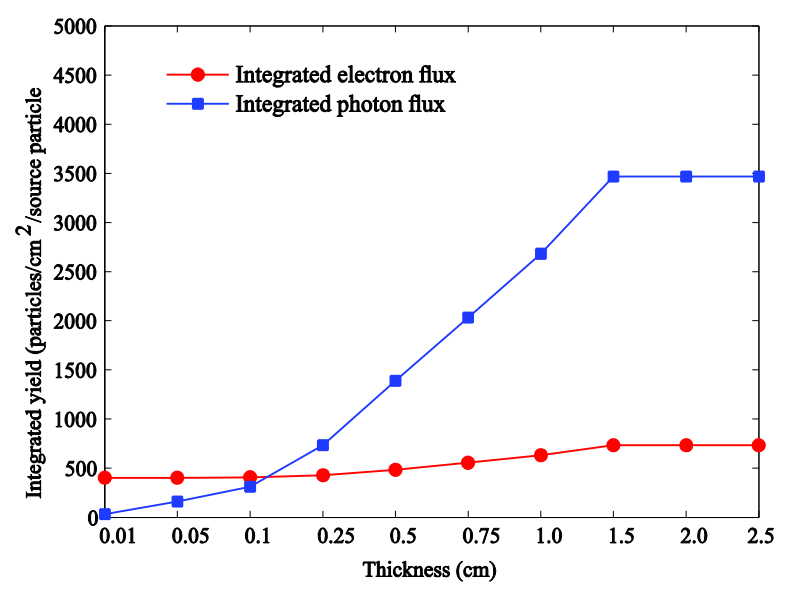

Fig. 4. Integrated flux over FMESH detection of bremsstrahlung photons and electrons for different thicknesses of copper. (See color Figure on the journal website.)

\subsection{Angular distribution}

In this section, the simulations provided the bremsstrahlung photon spectra and integrated flux at angles between 0 and $120^{\circ}$ from the copper target. Five thicknesses of the copper target were calculated. The angular energy spectra of bremsstrahlung photon from zero up to the maximum energy of the incident electron from five thicknesses are obtained. An example of the angular energy spectra from 0 to $20 \mathrm{MeV}$ from capper thickness of $0.25 \mathrm{~cm}$ shows in Fig 5. The bremsstrahlung photon flux presents a highest flux at the $0^{\circ}$ and reduces in the magnitude of four at $10^{\circ}$, approximately. At $30^{\circ}$, the angular energy spectrum shows the maximum energy at about $10 \mathrm{MeV}$ and reduces at the higher degree.

The integrated bremsstrahlung photon fluxes as a function of the angle and as a function of the target thickness are presented in Fig. 6 and Fig. 7, respectively. The bremsstrahlung photon flux showed the maximum value at $0^{\circ}$ and it decreased significantly about four orders of magnitude up to $20^{\circ}$. 


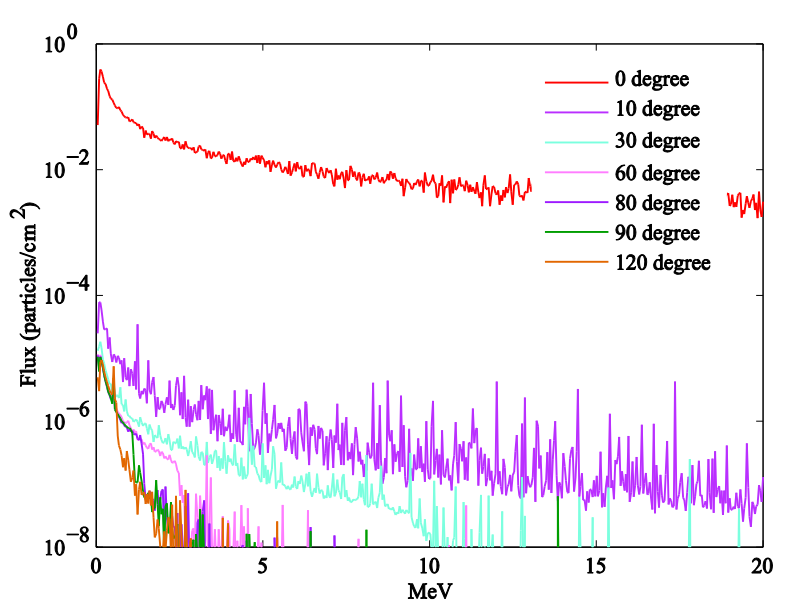

Fig. 5. The angular energy spectrum of bremsstrahlung photons for the copper target $0.25 \mathrm{~cm}$.

(See color Figure on the journal website.)

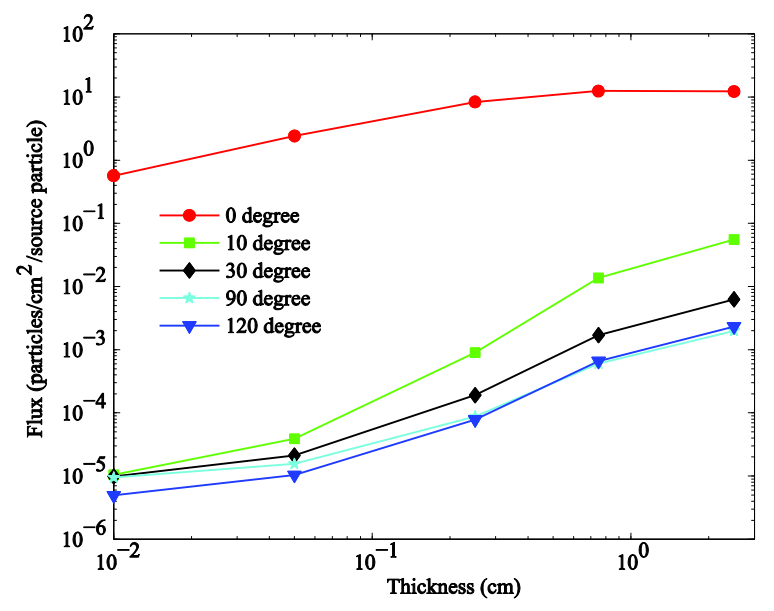

Fig. 7. Bremsstrahlung photon flux in function of thickness of copper target.

(See color Figure on the journal website.)

For the higher angles, the bremsstrahlung photon fluxes were constant. Additionally, for the copper thicknesses of $0.25,0.75$ and $2.5 \mathrm{~cm}$, the fluxes decreased exponentially against the angles.

Fig. 7 shows the relation of the integrated bremsstrahlung photon flux and the copper target thickness at different angles between 0 and $120^{\circ}$. At $0^{\circ}$, the bremsstrahlung photon flux slightly increased due to the increased copper thickness. At the higher angles from 10 to $120^{\circ}$, the integrated bremsstrahlung photon fluxes slightly increased for the copper thicknesses up to $0.05 \mathrm{~cm}$ and significantly increased for the thicknesses between 0.05 and $2.50 \mathrm{~cm}$.

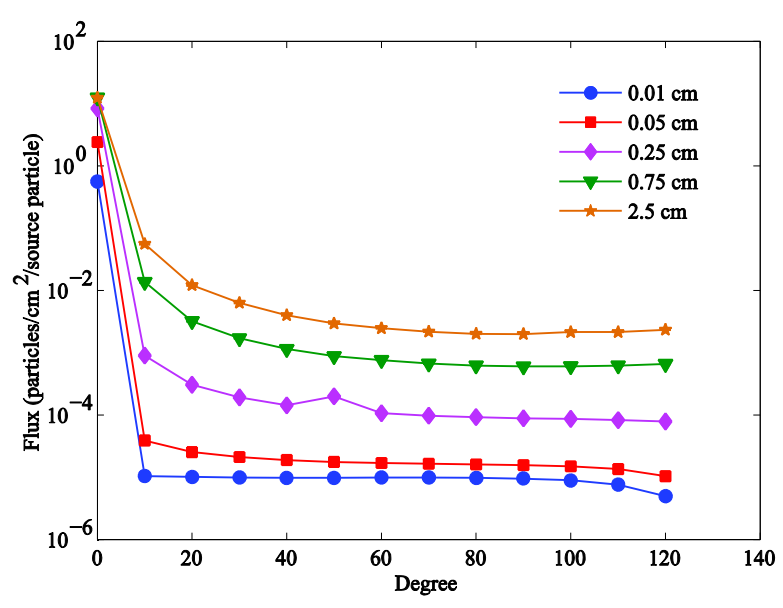

Fig. 6. Bremsstrahlung photon flux in function of angles of copper target.

(See color Figure on the journal website.)

\section{Conclusion}

Through the MCNP simulation of the bulk media target, the important parameter such as the material density and thickness are optimized and determined. The material density and thickness show the important role in the bremsstrahlung photon production. The high density material produces high bremsstrahlung photon flux, high bremsstrahlung photon scattered but low transmission electron. However, copper showed a high capability as a target for the $1 \mathrm{GeV}$ electrons due to the high bremsstrahlung photon production and low bremsstrahlung photon scattering flux. The thicknesses of the target have an influence on the bremsstrahlung photon production. The thick target produces a high bremsstrahlung photon flux. The bremsstrahlung photon flux is high at $0^{\circ}$ to the beam axis and decreases significantly up to $20^{\circ}$ to the beam axis for all thickness of the copper target.

The authors would like to express sincere thanks to the Department of Physics, Faculty of Science, Mahasarakham University. The authors acknowledge the High Performance Computing Server of the Thailand Institute of Nuclear Technology for providing computing resources that contributed to the research results reported within this paper.

\section{REFERENCES}

1. J.J. DeMarco et al. A verification of the Monte Carlo code MCNP for thick target bremsstrahlung calculations. Medical Physics 22 (1995) 11.

2. K. Kosako et al. Angular distribution of bremsstrahlung from copper and tungsten targets bombarded by 18,28 , and $38 \mathrm{MeV}$ electrons. Journal of Nuclear Science and Technology 47 (2010) 286.
3. S. Sujitjorn. Thai synchrotron facility: Its past and present. Suranaree Journal of Science and Technology 22(3) (2015) 227.

4. D.P. Gierga. Electron photon calculations using MCNP: Master Thesis (Massachusetts Institute of Technology, USA, 1996).

5. B.J. Patil et al. FLUKA simulation of $15 \mathrm{MeV}$ linear 
accelerator based thermal neutron source for radiography. Indian Journal of Pure \& Applied Physics 50 (2012) 814.

6. Q. Gao et al. Design and optimization of the target in electron linear accelerator. In: $4^{\text {th }}$ Intern. Particle Accelerator Conf. (Shanghai, China, 2013).
7. A. Tsechanski et al. A thin target approach for portal imaging in medical accelerators. Physics in Medicine and Biology 43 (1998) 2221.

8. J.E. Sweezy. Los Alamos National Laboratory: MCNP - A general Monte Carlo N-Particle transport code, version 5, LA-CP-03-0245 (2008).

\section{С. Сангарун*, В. Туйсакда}

Університет Махасарахам, факультет науки, фізичне відділення, Махасарахам, Таїланд

Відповідальний автор: siriyaporn.s@msu.ac.th

\section{ДОСЛІДЖЕННЯ ГАЛЬМІВНИХ ФОТОНІВ У ТОВСТІЙ МІШЕНІ З ВИКОРИСТАННЯМ КОДУ МСNР}

Метою даного дослідження є вивчення гальмівного $\gamma$-випромінювання при бомбардуванні мішеней 1 ГеВ електронами. Розрахунки виконані за допомогою Монте-Карло коду МCNP. Вивчено шість матеріалів для

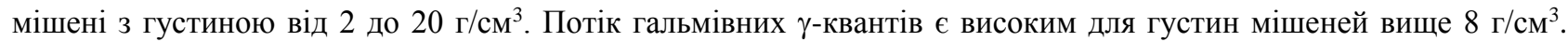
Мідь є найкращою мішенню для електронного пучка з енергією 1 ГеВ завдяки великому потоку гальмівних фотонів, невеликому розсіянню та низькому потоку електронів, що пройшли мішень. Для мідної мішені розрахунки проведено для товщин від 0,01 до 2,5 см. Результати показали, що потік гальмівних фотонів значно збільшується, коли товщина мішені збільшується від 0,01 до 1,5 см. Установлено кутовий розподіл гальмівних фотонів із кутами від 0 до 120 град для мішені з міді. Максимальний кут розсіювання фотонів становив близько 20 град.

Ключові слова: гальмівне випромінювання, електронний пучок, моделювання з МСNP.

\section{С. Сангарун*, В. Туйсакда}

Университет Махасарахам, факультет науки, отделение физики, Махасарахам, Таиланд

Ответственный автор: siriyaporn.s@msu.ac.th

\section{ИССЛЕДОВАНИЕ ТОРМОЗНЫХ ФОТОНОВ В ТОЛСТОЙ МИШЕНИ С ИСПОЛЬЗОВАНИЕМ КОДА МСNР}

Целью исследования было изучение тормозного $\gamma$-излучения при бомбардировке мишеней 1 ГэВ электронами. Расчеты выполнены с помощью Монте-Карло кода МCNP. Изучено шесть материалов для мишени с плотностью от 2 до 20 г/см³. Поток тормозных $\gamma$-квантов является высоким для плотностей мишеней

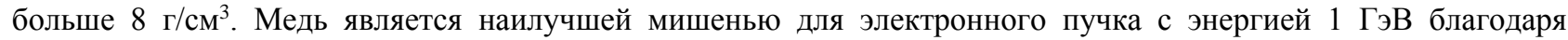
большому потоку тормозных фотонов, небольшому рассеянию и низкому потоку прошедших электронов. Для медной мишени расчеты проведены для толщин от 0,01 до 2,5 см. Результаты показали, что поток тормозных фотонов значительно увеличивается при увеличении толщины мишени от 0,01 до 1,5 см. Установлено угловое распределение тормозных фотонов с углами от 0 до 120 град для мишени из меди. Максимальный угол рассеяния фотонов был около 20 град.

Ключевые слова: тормозное излучение, электронный пучок, моделирование с MCNP.

Надійшла 07.12.2016

Received 07.12.2016 